\title{
Influence of vitamin E succinate on retinal cell survival
}

\author{
Ana Cristina Rego ${ }^{a}$, Maria Sancha Santos ${ }^{b}$, Maria Teresa Proença ${ }^{c}$, \\ Catarina R. Oliveira ${ }^{a, *}$ \\ a Center for Neurosciences of Coimbra, Faculty of Medicine, University of Coimbra, 3000 Coimbra, Portugal \\ ${ }^{\mathrm{b}}$ Department of Zoology, University of Coimbra, Coimbra, Portugal \\ ${ }^{\mathrm{c}}$ Neurological Clinic, HUC, Coimbra, Portugal
}

Received 24 November 1997; accepted 28 April 1998

\begin{abstract}
In this study, we analyzed the influence of vitamin E succinate $(5-80 \mu \mathrm{M})$, supplemented in the culture medium, on the survival of cultured retinal cells. The release of lactate dehydrogenase (LDH) was decreased in the presence of low concentrations $(10-20 \mu \mathrm{M})$ of vitamin E succinate, whereas high concentrations $(80 \mu \mathrm{M})$ induced a significant increase (about 2-fold) in the release of $\mathrm{LDH}$, indicating a reduction of plasma membrane integrity. Supplementing with vitamin E succinate $(80 \mu \mathrm{M})$ greatly enhanced its cellular content, as compared to vitamin E acetate $(80 \mu \mathrm{M})$, and the membrane order of the retinal cells, as evaluated by the fluorescence anisotropy ( $r$ ) of TMA-DPH (1-(4-(trimethylammonium)-phenyl)-6-phenylhexa-1,3,5-triene), was not altered. Furthermore, vitamin E succinate was more potent than vitamin $\mathrm{E}$ acetate in reducing thiobarbituric acid reactive substances (TBARS) formation upon ascorbate- $\mathrm{Fe}^{2+}$-induced oxidative stress (TBARS formation after cell oxidation decreased by about 15 -fold or 1.6 fold, respectively, in the presence of $20 \mu \mathrm{M}$ vitamin $\mathrm{E}$ succinate or $20 \mu \mathrm{M}$ vitamin $\mathrm{E}$ acetate). A decrease in MTT (3-(4,5-dimethylthiazol-2-yl)-2,5-diphenyltetrazolium bromide) reduction induced by supplementing with vitamin $\mathrm{E}$ succinate $(80 \mu \mathrm{M})$, to $35.99 \pm 1.96 \%$ as compared to the control, but not by vitamin $\mathrm{E}$ acetate $(80 \mu \mathrm{M})$, suggests that vitamin E succinate may affect the mitochondrial activity. Vitamin E succinate also reduced significantly the ATP:ADP ratio in a dose-dependent manner, indicating that vitamin E succinate-mediated cytotoxic effects involve a decrement of mitochondrial function. (C) 1998 Elsevier Science Ireland Ltd. All rights reserved.
\end{abstract}

Keywords: Cell viability; Neurotoxicity; Retinal cells; Vitamin E acetate; Vitamin E succinate

Abbreviations: BHT, 2,6-di-tert-butyl-4-methylphenol; BME, Basal Medium of Eagle; CNQX, 6-cyano-7-nitroquinoxaline-2,3dione; GR, glutathione reductase; GSH, reduced glutathione; GSSG, oxidized glutathione; LDH, lactate dehydrogenase; MK-801, (+ )-5-methyl-10,11-dihydro-5H-dibenzo(a,d)-cyclohepten-5,10-imine hydrogen maleate; MTT, 3-(4,5-dimethylthiazol-2-yl)-2,5diphenyltetrazolium bromide; NMDA, $N$-methyl-D-aspartate; TBA, thiobarbituric acid; TBARS, thiobarbituric acid reactive substances; TCA, tricarboxylic acid; TMA-DPH, 1-(4-(trimethylammonium)-phenyl)-6-phenylhexa-1,3,5-triene.

* Corresponding author. Tel.: + 35139 20190; fax: + 3513922776. 


\section{Introduction}

Vitamin E comprises eight naturally occurring fat-soluble derivatives, of which the most predominant, essential and with the highest biological activity is $\alpha$-tocopherol (Bjørneboe et al., 1990). $\alpha$-Tocopherol (referred to in this work as vitamin E) is a major antioxidant in biological systems, acting as a powerful chain-breaking agent through the scavenging of peroxyl radicals (Smith et al., 1993). Because oxidative damage has been postulated to be one of the causes of a variety of human diseases, the inhibition of peroxidation of polyunsaturated fatty acids by vitamin $\mathrm{E}$ is an important mechanism to avoid further cellular damage. Thus, a number of studies have been carried out to determine the protective effects of vitamin $\mathrm{E}$ in different biological models of injury. Vitamin E efficiency in protecting against radicalinduced injury was documented in primary cultures of the neuronal retina, after oxidation caused by cumene hydroperoxide (Amano et al., 1994), or after ascorbate- $\mathrm{Fe}^{2+}$-induced oxidative stress, through a decrease in the extent of lipid peroxidation (Agostinho et al., 1997). In endothelial cells, vitamin $\mathrm{E}$ decreased the production of hydrogen peroxide after hypoxia/reoxygenation (Martin et al., 1996). In C6 glioma cells, vitamin E completely blocked glutamate cell death and restored ATP levels (Yasui et al., 1996). Because vitamin $\mathrm{E}$ is located within the membranes, its efficiency in breaking chain propagation reactions is much higher than that of hydrophilic antioxidants, like Trolox or ascorbate, although they act as a synergist by reducing the vitamin E radical to regenerate vitamin $\mathrm{E}$ at the membrane surface (Niki et al., 1996).

In nature, vitamin $\mathrm{E}$ is found unesterified. Nevertheless, vitamin $\mathrm{E}$ esters are used in pharmacological formulations and dietary supplements because they are much more resistant to oxidation than the unesterified form. The esters themselves do not have antioxidant activity because the esterification masks the phenol moiety, but they release $\alpha$-tocopherol after enzymatic hydrolysis (reviewed in Liebler, 1993). The relatively nonpolar acetate ester ( $\alpha$-tocopherol acetate) is the most common form of vitamin $\mathrm{E}$ used as an oral sup- plement in humans, which is more stable than the free phenol form (Cheeseman et al., 1995). Although less commonly used, the succinate ester of vitamin $\mathrm{E}$ ( $\alpha$-tocopherol succinate) is more polar and resistant to oxidation and requires hydrolysis to release the active free phenol (Cheeseman et al., 1995). Previous studies describe the availability of $\alpha$-tocopherol from dietary vitamin $\mathrm{E}$ acetate and vitamin $\mathrm{E}$ succinate as similar to that of the unesterified form (reviewed in Liebler, 1993).

Because the range of concentrations and the efficiency of different forms of vitamin $E$ must be considered when using vitamin E for pharmacological formulations and dietary supplements, the purpose of the present study was to analyze the influence of vitamin $\mathrm{E}$ succinate, in comparison with vitamin $\mathrm{E}$ acetate, on the viability of retinal primary cell cultures, used as a neuronal model. Because vitamin $\mathrm{E}$ succinate was found to be cytotoxic when present in high concentrations, its therapeutical use in high doses as an antioxidant, in pathological situations in which oxidative stress is thought to be involved, namely in neurodegenerative disorders, should be carefully considered.

\section{Materials and methods}

\subsection{Materials}

Basal Medium of Eagle (Earle's salts, BME) was purchased from Sigma, Irvine, Scotland; trypsin from GIBCO and fetal calf serum from Biological Industries, Beth, Ha, Emek, Israel. 1-(4 - (Trimethylammonium) - phenyl) - 6 - phenylhexa 1,3,5-triene (TMA-DPH) was obtained from Molecular Probes, Eugene, OR. Vitamin E (D- $\alpha-$ tocopherol) succinate was obtained from Sigma, St. Louis, MO, whereas vitamin E (D- $\alpha$-tocopherol) acetate was purchased from Fluka (Sigma-Aldrich), Buchs, Switzerland. 6-Cyano-7nitroquinoxaline-2,3-dione (CNQX) was a kind gift of NOVO Nordisk, Denmark; and $(+)-5$ methyl-10,11-dihydro-5H-dibenzo(a,d)-cyclohepten-5,10-imine hydrogen maleate (MK-801) was from Merk Sharp and Dohme, West Point, PA. All other reagents were of analytical grade. 
2.2. Culture of chick retinal cells and incubation with vitamin $E$

Retinal cells were prepared from 8-day-old chick embryos, as previously described (Agostinho et al., 1994; Rego and Oliveira, 1995). Briefly, the retinas were dissected free from other ocular tissues and dissociated with $0.1 \%$ trypsin in a $\mathrm{Ca}^{2+}$ - and $\mathrm{Mg}^{2+}$-free Hank's balanced salt solution for 15 min, at $37^{\circ} \mathrm{C}$. The digested tissue was centrifuged at $500 \times g$ for $1 \mathrm{~min}$ and the pellet was resuspended in BME containing Earle's salts and L-glutamine, buffered with $25 \mathrm{mM}$ HEPES and $10 \mathrm{mM}$ $\mathrm{NaHCO}_{3}$, and supplemented with $5 \%$ fetal calf serum (heat inactivated), penicillin $(100 \mathrm{U} / \mathrm{ml})$ and streptomycin $(100 \mu \mathrm{g} / \mathrm{ml})$. Then the tissue was dissociated mechanically with a glass pipette and the retinal cells were further cultured in BME supplemented medium, as described. The cells were plated at a density of $0.64 \times 10^{6}$ cells $/ \mathrm{cm}^{2}$ on poly-L-lysine coated Costar multiwell plates or on poly-L-lysine coated glass coverslips, for fluorescence measurements. The retinal cells were cultured for 6 days at $37^{\circ} \mathrm{C}$ in an atmosphere of $95 \%$ air and $5 \% \mathrm{CO}_{2}$. Similar cultures of retinal cells were described as being enriched in amacrine neuron-like cells, but also containing neurons resembling bipolar cells and a few glial cells (Huba and Hofmann, 1990; Agostinho et al., 1996).

The retinal cell cultures at day 5 were supplemented with increasing concentrations of vitamin E succinate $(5-80 \mu \mathrm{M})$ or vitamin $\mathrm{E}$ acetate $(80$ $\mu \mathrm{M})$ in culture medium, and incubated for up to $24 \mathrm{~h}$ at $37^{\circ} \mathrm{C}$ in an atmosphere of $95 \%$ air and $5 \%$ $\mathrm{CO}_{2}$. The control cells were incubated in the absence of vitamin $\mathrm{E}$ supplementation, whereas other cells were incubated with the vehicle $(0.8 \%$ ethanol, maximal percentage).

\subsection{Analysis of cell survival}

The viability of retinal cells was determined by monitoring the leakage of lactate dehydrogenase $(\mathrm{LDH})$ or the capacity of the cells to reduce the 3-(4,5-dimethylthiazol-2-yl)-2,5-diphenyl tetrazolium bromide (MTT) salt to formazan, by the MTT colorimetric assay, upon incubation in the presence of vitamin $\mathrm{E}$.
LDH activity was measured spectrophotometrically, according to the method of Bergmeyer and Brent (1974), by following the rate of conversion of NADH to $\mathrm{NAD}^{+}$, at $340 \mathrm{~nm}$. The total $\mathrm{LDH}$ activity was determined after lysing the cells with $10 \mathrm{mM}$ Hepes, pH 7.4. LDH released into the extracellular medium, incubated with the cells for $20 \mathrm{~h}$, was expressed as a percentage of the total LDH activity in the cells.

The extent of reduction of MTT was measured spectrophotometrically at $570 \mathrm{~nm}$, according to Mosmann (1983). Briefly, $0.5 \mathrm{ml}$ MTT (final concentration $0.5 \mathrm{mg} / \mathrm{ml}$, in sodium saline solution), prepared just before use and maintained in the dark, was added to the retinal cells. After a $3 \mathrm{~h}$ incubation at $37^{\circ} \mathrm{C}$, required for MTT reduction, an equal volume of acid-isopropanol $(0.04 \mathrm{M} \mathrm{HCl}$ in isopropanol) was added and mixed thoroughly until all the formazan crystals were dissolved. The survival of retinal cells was expressed as the percentage of OD of control cells, in the absence of vitamin E.

\subsection{Analysis of adenine nucleotides}

The retinal cells pre-treated with vitamin $\mathrm{E}$ were washed twice with sodium saline solution, containing (in $\mathrm{mM}$ ): $\mathrm{NaCl} 140.0, \mathrm{KCl} 5.0, \mathrm{CaCl}_{2}$ 1.5, $\mathrm{MgCl}_{2} 1.0, \mathrm{NaH}_{2} \mathrm{PO}_{4}$ 1.0, glucose 5.6 and Hepes 20.0 , at $\mathrm{pH} 7.4\left(37^{\circ} \mathrm{C}\right)$. The cells were further extracted with $0.3 \mathrm{M}$ perchloric acid $\left(0-4^{\circ} \mathrm{C}\right)$ and centrifuged at $15800 \times g$, for $5 \mathrm{~min}$. The pellets were solubilized with $1 \mathrm{M} \mathrm{NaOH}$ and analyzed for total protein content by the Sedmak method (Sedmak and Grossero, 1977). The supernatants were neutralized with $10 \mathrm{M} \mathrm{KOH}$ in $5 \mathrm{M}$ Tris and centrifuged at $15800 \times g$ for $10 \mathrm{~min}$. The resulting supernatants were assayed for adenine nucleotides determination, by separation in a reversed-phase HPLC, as described by Stocchi et al. (1985). The chromatographic apparatus used was a Beckman System Gold, consisting of a Binary Pump model 126 and a Variable 166 UV detector, controlled by a computer. The column used was a Lichrospher 100 RP-18 (5 $\mu \mathrm{m})$ from Merck (Darmstadt, Germany). An isocratic elution with

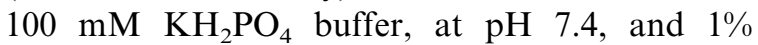
methanol was performed with a flow rate of 1.2 
$\mathrm{ml} / \mathrm{min}$. The adenine nucleotides (ATP, ADP and AMP) were detected at $254 \mathrm{~nm}$, for $6 \mathrm{~min}$.

\subsection{Induction and measurement of oxidative stress}

In other experiments, the oxidative stress was induced by incubating the retinal cells with ascorbic acid and $\mathrm{Fe}^{2+}$. Briefly, the culture medium in which the vitamin $\mathrm{E}$ was incubated was removed and the cells were pre-incubated for $10 \mathrm{~min}$ in sodium saline solution. Cell oxidation was induced with $5 \mathrm{mM}$ ascorbate and $100 \mu \mathrm{M} \mathrm{Fe}^{2+}$ in sodium solution, at $\mathrm{pH} 6.5\left(37^{\circ} \mathrm{C}\right)$ for $15 \mathrm{~min}$. Control conditions were carried out in the absence of the oxidizing agents at $\mathrm{pH}$ 7.4. The reaction was stopped by removing the incubation medium and by adding $0.5 \mathrm{ml}$ ice-cold $15 \mathrm{mM}$ Tris ( $\mathrm{pH} 7.4$ ), $0.5 \mathrm{ml} 40 \%$ tricarboxylic acid (TCA) (w/v) and $4.5 \mu 1267 \mathrm{mM}$ 2,6-di-tert-butyl4-methylphenol (BHT) with the plates already on ice at $0-4^{\circ} \mathrm{C}$. The cells were scraped and thiobarbituric acid reactive substances (TBARS) were determined using the thiobarbituric acid (TBA) method, according to Wills (1969): $2 \mathrm{ml} 0.67 \%$ TBA were added and the samples were placed in a boiling waterbath for $15 \mathrm{~min}$. After cooling, the samples were centrifuged at $3000 \mathrm{rpm}$ in a SIGMA-302 K centrifuge, for $10 \mathrm{~min}$, and the supernatants were collected. An absorption coefficient of $1.56 \times 10^{5} \mathrm{M}^{-1} \mathrm{~cm}^{-1}$ at $530 \mathrm{~nm}$ was used for calculating the amount of TBARS produced, expressed as $\mathrm{nmol} / \mathrm{mg}$ protein. The amount of protein was determined by following the Sedmak method (Sedmak and Grossero, 1977).

\subsection{Glutathione reductase activity measurements}

The activity of glutathione reductase (GR) in cultures of the retinal cells was measured spectrophotometrically after lysing the cells with an hypotonic solution containing $10 \mathrm{mM}$ Hepes, $\mathrm{pH}$ 7.4, since GR, the enzyme responsible for the maintenance of intracellular reduced glutathione (GSH), is found in the soluble fraction of the cells. GR activity of the retinal samples stored at $-20^{\circ} \mathrm{C}$ was determined by following the rate of conversion of NADPH to $\mathrm{NADP}^{+}$at $339 \mathrm{~nm}$. The cuvettes contained $2.6 \mathrm{ml}$ phosphate buffer (0.12 $\left.\mathrm{M} \mathrm{KH}_{2} \mathrm{PO}_{4}, \mathrm{pH} 7.2\right), 0.1 \mathrm{ml} 15 \mathrm{mM}$ EDTA, $0.1 \mathrm{ml} 65.3 \mathrm{mM}$ oxidized glutathione (GSSG) and $0.1 \mathrm{ml}$ of the sample, which were thoroughly mixed for $5 \mathrm{~min}$ at $37^{\circ} \mathrm{C}$. The reaction was initiated by adding $0.05 \mathrm{ml} 9.6 \mathrm{mM} \quad \beta$-NADPH. $\beta$-NADPH or GSSG solutions were freshly prepared in $1 \%(\mathrm{w} / \mathrm{v}) \mathrm{NaHCO}_{3}$ or water, respectively. The rate of absorbance decrease, due to NADPH oxidation, was measured against air and monitored at $30 \mathrm{~s}$ intervals for $1 \mathrm{~min}$ at $37^{\circ} \mathrm{C}$ in a Perkin Elmer Lambda-2 thermostatized spectrophotometer. The results were expressed as the catalytic activity of GR related to the amount of protein, in $\mathrm{U} / \mathrm{mg}$ protein.

\subsection{Retinal cell content in vitamin $E$}

At the end of the incubation with vitamin $\mathrm{E}$, the retinal cells were lysed with $15 \mathrm{mM}$ Tris, $\mathrm{pH}$ 7.4 , scraped and homogenized. The extraction and separation of endogenous membrane-containing vitamin $\mathrm{E}$ was performed by following the methods described by Vatassery et al. (1978), Leenheer et al. (1979) and Burton et al. (1985). To $0.5 \mathrm{ml}$ of the cell suspension, $1.5 \mathrm{ml} 10 \mathrm{mM}$ SDS was added, followed by addition of $2 \mathrm{ml}$ ethanol. Then, $2 \mathrm{ml} n$-hexane and $50 \mu 13 \mathrm{M} \mathrm{KCl}$ were added, and vortexed for about $3 \mathrm{~min}$. The extract was centrifuged at $2000 \mathrm{rpm}$, for $3 \mathrm{~min}$, in a SIGMA 302-K centrifuge to allow phase separation. The upper phase $(1 \mathrm{ml})$ containing $n$-hexane (the $n$-hexane layer) was recovered and evaporated to dryness under a stream of $\mathrm{N}_{2}$, and kept at $-80^{\circ} \mathrm{C}$. The extract was redissolved in $n$-hexane and vitamin $\mathrm{E}$ was analyzed by reversed-phase HPLC. A $4.6 \mathrm{~mm} \times 200 \mathrm{~mm}$, Spherisorb S10w column was eluted with $n$-hexane modified with $0.9 \%$ methanol, at a flow of $1.5 \mathrm{ml} / \mathrm{min}$. Detection was performed by UV absorbance, at $287 \mathrm{~nm}$.

\subsection{Membrane anisotropy measurements}

The membrane order of the retinal cells pre-exposed to vitamin $\mathrm{E}$ was measured by fluorescence analysis in glass coverslips, by using the probe TMA-DPH. The coverslips were rinsed with a 
sodium saline solution at $\mathrm{pH}$ 7.4. The coverslips were placed in a special holder (Perkin-Elmer L225008) allowing an alignment at an angle near $60^{\circ}$ to the excitation beam in a temperature-controlled cuvette in order to minimize the effect of light reflection. The cells were further incubated with $1.5 \mu \mathrm{M}$ TMA-DPH (dissolved in $N, N$ dimethylformamide and maintained in the dark) in $1.5 \mathrm{ml}$ sodium saline solution, for $20 \mathrm{~min}$, at $37^{\circ} \mathrm{C}$. Preliminary tests have shown that the probe is rapidly incorporated in both cells non-treated and treated with vitamin E, the labelling of cultured cells by TMA-DPH being maximal after about 15-20 min. Constant anisotropy $(r)$ values were observed at least up to 30 min-incubation with TMA-DPH. Fluorescence anisotropy $(r)$ was determined in a computer-assisted Perkin-Elmer LS 50 B spectrofluorophotometer, equipped with a thermostated cuvette holder and with a controlled polarizer system, with excitation at $360 \mathrm{~nm}$ and emission at $430 \mathrm{~nm}$. The fluorescence anisotropy data were calculated according to Shinitzky and Barenholz (1978), and determined by the formula:

$r=I_{\|}-I_{\perp} / I_{\|}+2 I_{\perp}$,

where $I_{\|}$and $I_{\perp}$ are the intensities of the emitted light whose plane of polarization is oriented, respectively, parallel and perpendicular to the plane of polarization of the excitation beam. An increase in fluorescence anisotropy $(r)$ values reflects a decrease in the probe mobility and an increase in the membrane structural order and/or a decrease in membrane 'fluidity' (Van Blitterswijk et al., 1981). Nonlabelled cells at the excitation wavelength of $360 \mathrm{~nm}$ and the emission wavelength of $430 \mathrm{~nm}$ gave total fluorescence intensities of less than $10 \%$ of the signal with TMA-DPH.

\subsection{Data analysis}

Throughout the text, data are expressed as mean \pm S.E.M. of the indicated number of experiments. Statistical significance was determined by using the unpaired Student's $t$-test $(P<0.05$ was considered significant).

\section{Results}

\subsection{Effect of vitamin E succinate on the survival} of retinal cells

The survival of the retinal cells submitted to vitamin $\mathrm{E}$ succinate supplementation was analyzed by the release of $\mathrm{LDH}$, which is indicative of irreversible membrane disruption and cell death, and by the reduction of MTT, suggested to be a measure of the mitochondria activity (Mosmann, 1983; Keller et al., 1997). Fig. 1 shows that the leakage of LDH varied depending on the concentration of vitamin E succinate supplementing the culture medium for $20 \mathrm{~h}$. LDH leakage was significantly lower, as compared to the control $(19.22 \pm 1.41 \%)$, in the presence of $10 \mu \mathrm{M}$ $(8.59 \pm 0.75 \%)$ or $20 \mu \mathrm{M}(5.71 \pm 0.24 \%)$ vitamin E succinate, indicating an increase in the integrity of the plasma membrane. In the presence of 80 $\mu \mathrm{M}$ vitamin $\mathrm{E}$ succinate, the release of $\mathrm{LDH}$ increased significantly $(35.45 \pm 2.70 \%)$, indicating cell toxicity (Fig. 1).

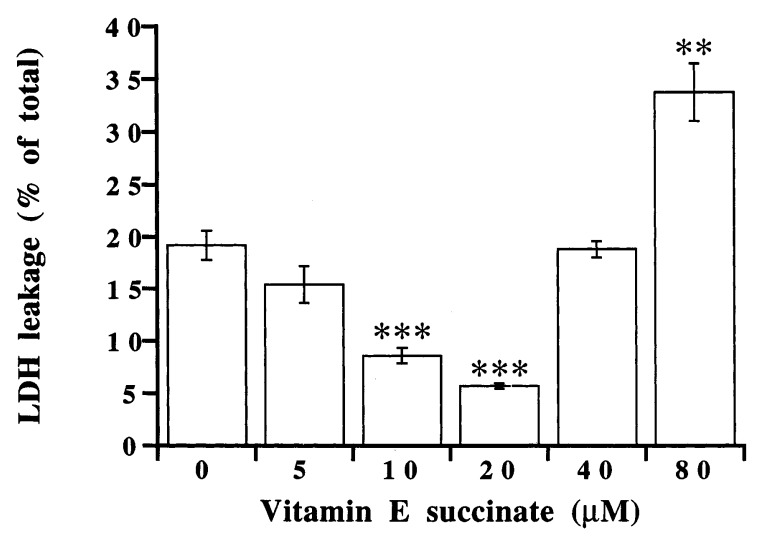

Fig. 1. Effect of vitamin E succinate on LDH leakage. Cultures of the retinal cells were supplemented with vitamin $\mathrm{E}$ succinate $(5,10,20,40$ or $80 \mu \mathrm{M})$ and incubated for $20 \mathrm{~h}$ at $37^{\circ} \mathrm{C}$ in an atmosphere of $95 \%$ air and $5 \% \mathrm{CO}_{2}$. Then the medium was recovered and $\mathrm{LDH}$ was measured by following the conversion of NADH to $\mathrm{NAD}^{+}$, at $340 \mathrm{~nm}$. Retinal cells were lysed after incubation with ice-cold $10 \mathrm{mM}$ Hepes, $\mathrm{pH}$ 7.4. $\mathrm{LDH}$ released into the extracellular medium was expressed as a percentage of the total (intra- plus extracellular) LDH activity in the cells. The data are the mean \pm S.E.M. from seven to twenty-three determinations, in duplicate. Statistical significance: $* * P<0.01$ or $* * * P<0.001$ as compared to the control, in the absence of vitamin E succinate. 

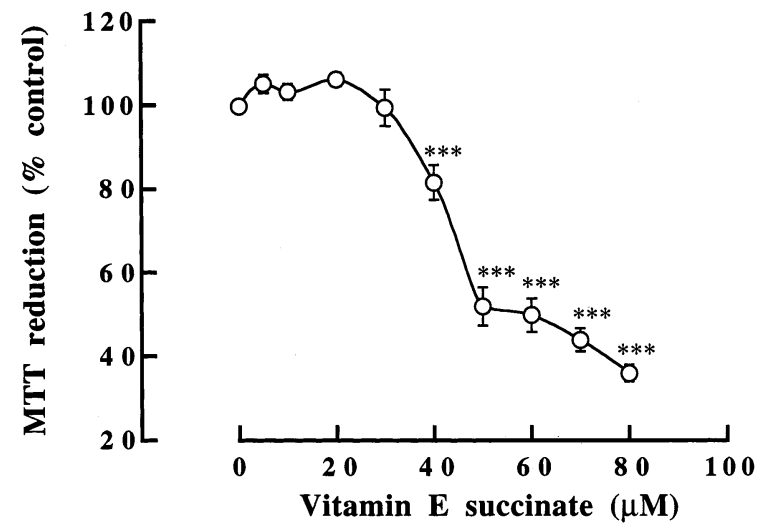

Fig. 2. Dose-dependent changes in MTT reduction induced by vitamin E succinate. The cells were supplemented with vitamin E succinate $(5-80 \mu \mathrm{M})$ for $20 \mathrm{~h}$, whereas the control cells were not exposed to vitamin E succinate. At the end of the incubation, the culture medium was removed and the cells were incubated with MTT $(0.5 \mathrm{mg} / \mathrm{ml})$, for $3 \mathrm{~h}$. MTT reduction was examined spectrophotometrically at $570 \mathrm{~nm}$ after addition of acid-isopropanol. Data, expressed as a percentage of control, are the mean \pm S.E.M. from eight experiments, run in duplicate or triplicate. Statistical significance: ${ }^{*} P<0.05,{ }^{* *} P<0.01$ or $* * * P<0.001$ in comparison with the control, not submitted to vitamin $\mathrm{E}$ treatment.

LDH data were compared to the morphological observation of the retinal cells submitted to vitamin E succinate, for $20 \mathrm{~h}$. Similarly to $\mathrm{LDH}$ leakage measurements, $20 \mu \mathrm{M}$ vitamin $\mathrm{E}$ succinate did not cause significant changes in the cell morphology (not shown). However, incubation with $40 \mu \mathrm{M}$ vitamin $\mathrm{E}$ succinate altered the normal morphology of retinal neurons. Under these conditions the neurons were grouped in clusters, but the dendrites and axons were maintained. In the presence of $80 \mu \mathrm{M}$ vitamin $\mathrm{E}$ succinate, the dendrites and axons were completely lost, leading to major cellular degeneration. In the presence of $80 \mu \mathrm{M}$ vitamin $\mathrm{E}$ acetate or in the presence of $0.8 \%$ ethanol, their normal morphology was maintained (not shown).

The survival of the retinal cell was also analyzed by the MTT method (Figs. 2-4). Fig. 2 shows that in the presence of low concentrations of vitamin $\mathrm{E}$ succinate $(5-20 \mu \mathrm{M})$ cell survival was preserved. Nevertheless, increasing the concentration of vitamin $\mathrm{E}$ succinate up to $80 \mu \mathrm{M}$ induced a dose-dependent decrease in the capacity of the cells to reduce MTT (Fig. 2), suggesting that the mitochondrial activity was affected. Incubation with $40 \mu \mathrm{M}$ vitamin E succinate decreased MTT reduction to $81.59 \pm 4.15 \%$, whereas in the presence of $80 \mu \mathrm{M}$ vitamin E succinate, the MTT reduction was $35.99 \pm 1.96 \%$, a decrease of about $64 \%$ in comparison with the control (Fig. 2). Moreover, $0.8 \%$ ethanol, the maximal percentage of vehicle used, did not significantly affect the reduction of MTT (Fig. 3). Incubation with vitamin $\mathrm{E}$ acetate $(80 \mu \mathrm{M})$ did not change MTT reduction as compared to the control (Fig. 3), indicating that the alteration of cell survival and/ or mitochondrial activity was only observed after treatment with the form of vitamin $\mathrm{E}$ esterified with succinate. As observed in Fig. 4, $80 \mu \mathrm{M}$ vitamin $\mathrm{E}$ succinate mediated changes in MTT reduction were time-dependent and achieved maximal effects after $20-24 \mathrm{~h}$ incubation. In this study we also observed that $80 \mu \mathrm{M}$ vitamin $\mathrm{E}$ succinate-induced loss in cell survival was not associated with the activation of glutamate receptors due to the release of excitatory amino acids, a common feature of neurotoxicity in retinal cells

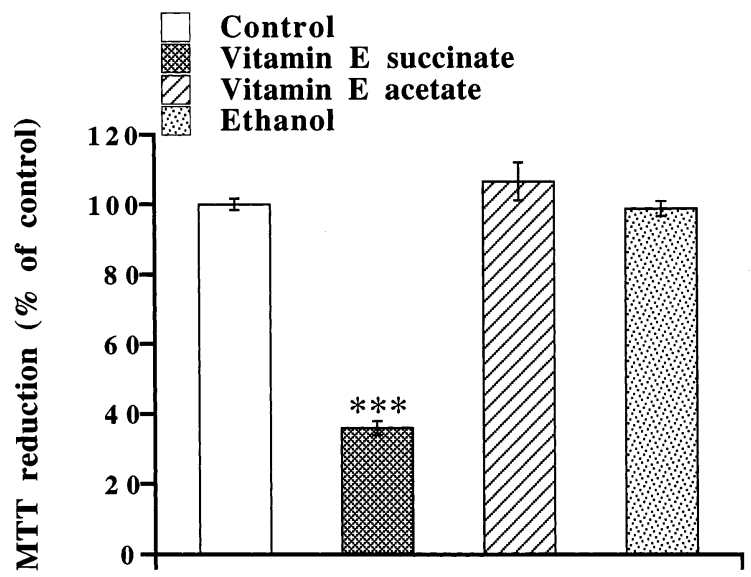

Fig. 3. Effect of vitamin $\mathrm{E}$ succinate, vitamin $\mathrm{E}$ acetate or ethanol on the reduction of MTT. The retinal cells were supplemented in the culture medium with vitamin E succinate $(80 \mu \mathrm{M})$, vitamin $\mathrm{E}$ acetate $(80 \mu \mathrm{M})$ or ethanol $(0.8 \%)$ for 20 h. Then, the cells were incubated with MTT $(0.5 \mathrm{mg} / \mathrm{ml})$, for 3 h. MTT reduction was examined spectrophotometrically at $570 \mathrm{~nm}$. Data, expressed as a percentage of control, are the mean \pm S.E.M. from two to three experiments run in triplicate. Statistical significance: ${ }^{* * *} P<0.001$ as compared to the control. 
$\multimap-80 \mu M$ Vitamin E succinate

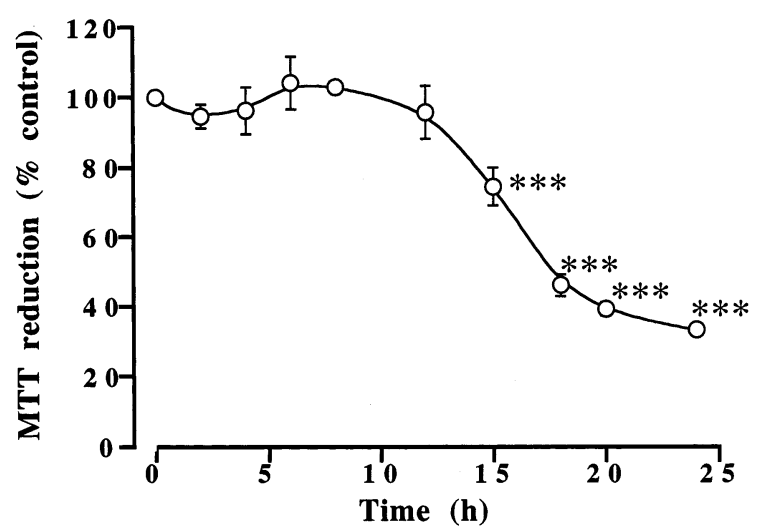

Fig. 4. Time-dependent changes in MTT reduction induced by vitamin $\mathrm{E}$ succinate. The retinal cells were incubated with 80 $\mu \mathrm{M}$ vitamin $\mathrm{E}$ succinate for up to $24 \mathrm{~h}$. MTT reduction was determined as described in Fig. 2. The results are the mean \pm S.E.M. of four experiments run in triplicates. Statistical significance: ${ }^{* * *} P<0.001$ as compared to the reduction of MTT observed before incubation with vitamin $\mathrm{E}$ succinate.

in culture. In fact, a mixture of drugs composed of $7.5 \mu \mathrm{M}$ MK-801 and $10 \mu \mathrm{M}$ CNQX, respectively, an inhibitor of $N$-methyl-D-aspartate (NMDA) and an inhibitor of non-NMDA receptors, incubated $45 \mathrm{~min}$ prior to the addition of vitamin $\mathrm{E}$ and during the incubation with vitamin E succinate $(40-80 \mu \mathrm{M})$ for $20 \mathrm{~h}$ did not significantly affect the reduction of MTT observed after treatment with vitamin $\mathrm{E}$ succinate in the absence of MK-801 and CNQX (not shown).

\subsection{Effect of vitamin E succinate on the levels of adenine nucleotides}

Because the decreased capacity of cells to reduce the MTT salt has been referred to depend upon the normal activity of mitochondria (Mosmann, 1983; Keller et al., 1997), we measured the intracellular levels in adenine nucleotides. Fig. 5 shows the alteration of the ratio ATP:ADP after treatment with vitamin E succinate $(20-80 \mu \mathrm{M})$, for $20 \mathrm{~h}$. Similarly to that seen in Fig. 2 (dose-response curve of MTT reduction), the ATP:ADP ratio decreased in a a dose-dependent manner upon incubation of the retinal cells with $40 \mu \mathrm{M}$ $(9.09 \pm 0.98)$ and up to $80 \mu \mathrm{M}(2.93 \pm 0.42)$ vita- min $\mathrm{E}$ succinate, as compared to the control $(15.53 \pm 0.50)$, in the absence of vitamin E (Fig. $5)$. In the presence of $0.8 \%$ ethanol, the ATP:ADP ratio was $16.19 \pm 1.26$, a value not statistically different from data obtained in non-treated cells. The changes in ATP:ADP ratio followed a dosedependent decrease in endogenous ATP, whereas the levels of ADP were not significantly altered (not shown).

\subsection{Influence of preincubation of vitamin $E$ on cell oxidation and glutathione reductase activity}

Because high concentrations of vitamin E succinate $(80 \mu \mathrm{M})$ were shown to cause irreversible cell damage, as determined by $\mathrm{LDH}$ leakage, and a significant reduction in mitochondria activity, closely related to a decrease in ATP levels, we determined whether vitamin E succinate could still act as a potent antioxidant in cultured retinal cells, through the scavenging of peroxyl radicals formed after cell oxidation induced with ascorbate $-\mathrm{Fe}^{2+}$. Oxidative stress induced with $5 \mathrm{mM}$ ascorbate and $100 \mu \mathrm{M} \mathrm{Fe}^{2+}$ at $\mathrm{pH} 6.5$ was previously found to increase the lipid peroxidation in co-cultures of retinal cells, as determined by the

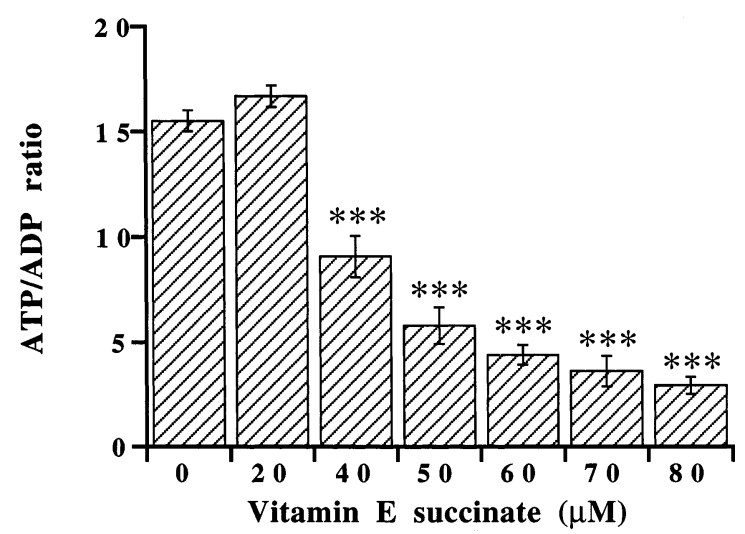

Fig. 5. Dose-dependent changes in the ATP:ADP ratio induced by vitamin E succinate. After a 20 h-incubation with vitamin E succinate $(20-80 \mu \mathrm{M})$ in culture medium, the retinal cells were extracted with perchloric acid and further neutralized with $\mathrm{KOH}$-Tris. The samples were assayed for adenine nucleotide determination, by separation in a reversed-phase HPLC. Data are the mean \pm S.E.M. from four to five experiments run in triplicate. Statistical significance: ${ }^{* * *} P<0.001$ as compared to the control, not exposed to vitamin E succinate. 


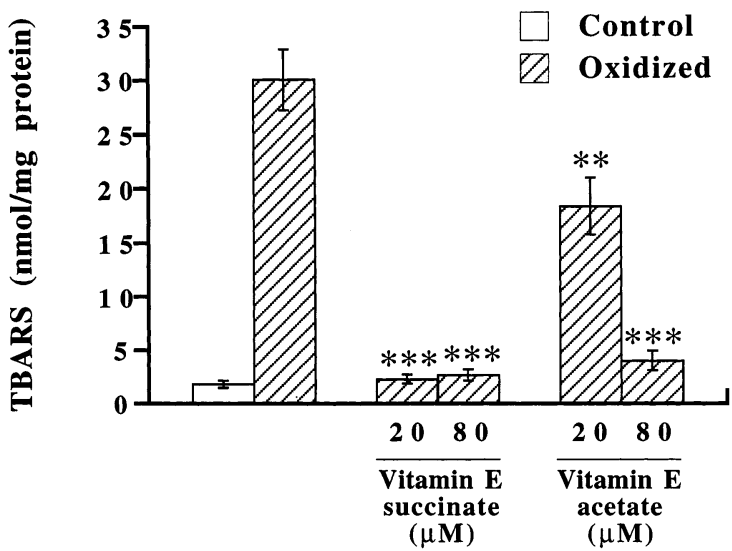

Fig. 6. Effect of preincubation of vitamin $\mathrm{E}$ esters on the extent of cell oxidation induced by ascorbate $-\mathrm{Fe}^{2+}$. Oxidative stress was induced with ascorbate $(5 \mathrm{mM})-\mathrm{Fe}^{2+}(100 \mu \mathrm{M})$ at $\mathrm{pH} 6.5$ for $15 \mathrm{~min}$, whereas the control was incubated in the absence of the oxidizing agents, at $\mathrm{pH}$ 7.4. Vitamin E succinate $(20$ or $80 \mu \mathrm{M})$ or vitamin $\mathrm{E}$ acetate $(20$ or $80 \mu \mathrm{M})$ were incubated for $20 \mathrm{~h}$ in the culture medium, prior to the induction of oxidative stress. The extent of cell oxidation was determined by the TBA method and expressed as nmol TBARS $/ \mathrm{mg}$ protein. The results are the mean \pm S.E.M. of four experiments run in duplicates. Statistical significance: ${ }^{* *} P<$ 0.01 or $* * * P<0.001$ as compared to the cells not treated with vitamin $\mathrm{E}$ and oxidized in the presence of ascorbate $-\mathrm{Fe}^{2+}$.

formation of TBARS and conjugated dienes (Rego et al., 1996). Fig. 6 shows that the oxidation with ascorbate- $\mathrm{Fe}^{2+}$ for $15 \mathrm{~min}$ increased the production of TBARS, by about 17 -fold. Preincubation of vitamin $\mathrm{E}$ succinate $(20 \mu \mathrm{M}$ or 80 $\mu \mathrm{M}$ ) for $20 \mathrm{~h}$ was shown to greatly reduce the extent of cell oxidation to TBARS values close to the control, in the absence of ascorbate- $\mathrm{Fe}^{2+}$ (Fig. 6). Nevertheless, preincubation of vitamin E acetate only partially reduced the production of TBARS: from $30.11 \pm 2.83 \mathrm{nmol} / \mathrm{mg}$ protein after oxidative stress, in the absence of vitamin $\mathrm{E}$, to $18.39 \pm 2.60 \mathrm{nmol} / \mathrm{mg}$ protein after oxidative stress in cells preincubated with $20 \mu \mathrm{M}$ vitamin $\mathrm{E}$ acetate (Fig. 6). Vitamin E acetate $(80 \mu \mathrm{M})$ enhanced the protection against ascorbate- $\mathrm{Fe}^{2+}$ oxidative stress, as compared to $20 \mu \mathrm{M}$ vitamin $\mathrm{E}$ acetate $(4.02 \pm 0.92 \mathrm{nmol} \mathrm{TBARS} / \mathrm{mg}$ protein were formed), although it was not as effective as $80 \mu \mathrm{M}$ vitamin $\mathrm{E}$ succinate $(2.69 \pm 0.51 \mathrm{nmol}$ TBARS/mg protein), as shown in Fig. 6.
In order to try to explain the increased protection against retinal cell oxidation afforded by vitamin $\mathrm{E}$ succinate, as compared to vitamin $\mathrm{E}$ acetate, we determined the catalytic activity of GR (Fig. 7), an enzyme responsible for converting GSSG into GSH, thus replenishing the intracellular antioxidant levels responsible for the reduction of oxidized protein thiol groups, amongst others. An increase (about 6-fold, $P<0.01$ ) in the activity of GR was observed only after incubation with 80 $\mu \mathrm{M}$ vitamin $\mathrm{E}$ succinate, for $20 \mathrm{~h}$ (Fig. 7). Preincubation with $80 \mu \mathrm{M}$ vitamin $\mathrm{E}$ acetate did not significantly affect GR activity, as compared to the retinal cells not incubated with vitamin $\mathrm{E}$ (control). These data indicated that in the presence of vitamin E succinate the antioxidant capacity is enhanced in comparison with vitamin $\mathrm{E}$ acetate.

\subsection{Influence of exposure to vitamin E esters on the total cellular content of vitamin $E$}

The retinal cell content in vitamin $\mathrm{E}$ was analyzed by HPLC after supplementation of the cells with vitamin $\mathrm{E}$ succinate or vitamin $\mathrm{E}$ acetate. We chose the concentration of $80 \mu \mathrm{M}$ for both forms of vitamin $\mathrm{E}$, because this was the concentration that induced major changes in cell survival (Figs. 1-4) or antioxidant capacity (Figs. 6 and 7). Data from Table 1 show that, although there was great variability between the various experiments, a significant increment in the amount of vitamin $\mathrm{E}$ incorporated in the retinal cells occurred after exposure to vitamin E succinate (Table 1). Only a small, but not significant, increase in the cellular content of vitamin $\mathrm{E}$ was observed after incubation with the same concentration of vitamin $E$ acetate (Table 1). The exposure of the retinal cells to $0.8 \%$ ethanol did not significantly affect the levels of endogenous vitamin $\mathrm{E}$, as compared to the control (not shown).

\subsection{Effect of vitamin E succinate on membrane anisotropy}

Because the cytotoxic effects of vitamin E succinate supplementation, associated with an increase in the endogenous content of vitamin $\mathrm{E}$ (Table 1) 


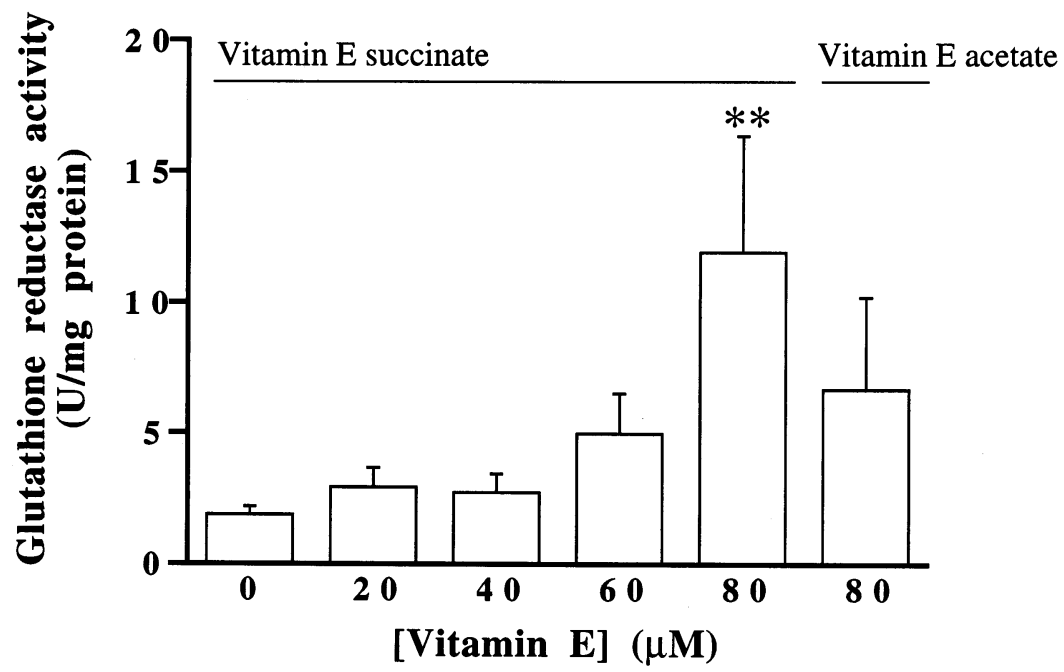

Fig. 7. Influence of vitamin $\mathrm{E}$ on the activity of glutathione reductase. The retinal cells were incubated with vitamin $\mathrm{E}$ succinate (20, $40,60$ or $80 \mu \mathrm{M})$ or vitamin $\mathrm{E}$ acetate $(80 \mu \mathrm{M})$ in the culture medium, for $20 \mathrm{~h}$. The endogenous activity of GR was determined by following the decrease in absorbance due to NADPH oxidation, in the presence of GSSG, at $37^{\circ} \mathrm{C}$. The results, expressed as the catalytic activity of $\mathrm{GR}$, in $\mathrm{U} / \mathrm{mg}$ protein, are the mean \pm S.E.M. of three experiments run in triplicates. Statistical significance: ${ }^{* *} P<0.01$ as compared to the control, in the absence of vitamin E.

could induce some destabilization of the membrane structure, we measured the effect of increasing concentrations of vitamin $\mathrm{E}$ succinate on the membrane anisotropy of retinal cells, by using the probe TMA-DPH (Table 2). This probe was previously used to detect changes in the outer leaflet membrane order of retinal cells in culture (Rego and Oliveira, 1995). As observed in Table 2, none of the concentrations of vitamin E succinate used significantly altered the membrane order of retinal cells in culture, indicating that the cytotoxicity, observed after exposure to vitamin E succinate (80 $\mu \mathrm{M})$, was not due to plasma membrane destabilization.

\section{Discussion}

In this study we found that depending on the form and concentration of vitamin E, it may increase cell survival or cause cytotoxic effects in retinal cells in culture, used as a model for a neuronal system. Low concentrations of vitamin E succinate decreased LDH release (Fig. 1) and preserved cell survival (Fig. 2), suggesting some protective effects induced by this form of vitamin E. Nevertheless, high concentrations of vitamin $\mathrm{E}$ succinate $(80 \mu \mathrm{M})$ significantly increased the release of LDH (approximately $40 \%$ of the total), indicative of irreversible plasma membrane damage (Fig. 1), and greatly decreased the efficacy of the retinal cells to reduce MTT after a prolonged (20-24 h) exposure (Fig. 4). The cytotoxic effects mediated by vitamin $\mathrm{E}$ succinate (above $25 \mu \mathrm{M}$ )

Table 1

Retinal cell content of unesterified vitamin $\mathrm{E}$ after exposure to the vitamin $\mathrm{E}$ esters acetate and succinate

\begin{tabular}{lc}
\hline $\begin{array}{l}\text { Incubation in culture } \\
\text { medium }\end{array}$ & $\begin{array}{l}\text { Vitamin } \mathrm{E} \\
(\mathrm{nmol} / \mathrm{mg} \text { protein })\end{array}$ \\
\hline Control & $1.40 \pm 0.98$ \\
$80 \mu \mathrm{M}$ vitamin E acetate & $5.38 \pm 3.62$ \\
$80 \mu \mathrm{M}$ vitamin E succinate & $163.21 \pm 37.83 *$ \\
\hline
\end{tabular}

The retinal cells were incubated with vitamin E succinate ( 80 $\mu \mathrm{M})$ or vitamin $\mathrm{E}$ acetate $(80 \mu \mathrm{M})$ for $20 \mathrm{~h}$. Then, the cells were disrupted with SDS and the vitamin E was extracted with $n$-hexane as described in Section 2. Vitamin E (unesterified $\alpha$-tocopherol) was analyzed by reversed-phase HPLC. The data are the mean \pm S.E.M. from five to six determinations. Statistical significance: $* P<0.05$ as compared to the control, in the absence of exogenous vitamin $\mathrm{E}$. 
Table 2

Effect of vitamin E succinate on the membrane order of retinal cells in culture

\begin{tabular}{ll}
\hline Vitamin E succinate $(\mu \mathrm{M})$ & Anisotropy values $(r)$ \\
\hline Control & $0.407 \pm 0.002$ \\
20 & $0.413 \pm 0.004$ \\
40 & $0.409 \pm 0.002$ \\
60 & $0.416 \pm 0.002$ \\
80 & $0.412 \pm 0.002$ \\
\hline
\end{tabular}

The retinal cells, cultured on glass coverslips, were incubated with vitamin $\mathrm{E}$ succinate $(20-80 \mu \mathrm{M})$ for $20 \mathrm{~h}$ in the culture medium. Then, the cells were incubated with $1.5 \mu \mathrm{M}$ TMADPH and anisotropy $(r)$ values were measured after $20 \mathrm{~min}$, at $37^{\circ} \mathrm{C}$. The results are the mean \pm S.E.M. from eight to fifteen determinations for each concentration tested.

were previously observed in L1210 murine lymphocytic leukemia cells, as determined by trypan blue dye exclusion (Kelley et al., 1995). Furthermore, although cell death has been frequently associated with the fragmentation of DNA, incubation of the retinal cells with the vitamin $\mathrm{E}$ esters, succinate or acetate $(80 \mu \mathrm{M})$ for $20 \mathrm{~h}$ did not induce DNA laddering, as compared to control cells (author's unpublished data).

The antioxidant effects of vitamin $\mathrm{E}$ have been extensively described (Fariss, 1990; Smith et al., 1993; Mabile et al., 1995; Martin et al., 1996). In retinal cells in culture, despite a significant decrease in cell survival, vitamin E succinate showed an effective antioxidant capacity. Vitamin E succinate $(80 \mu \mathrm{M})$ increased the enzymatic activity of GR (Fig. 7), suggesting increased formation of GSH. Moreover, vitamin E succinate demonstrated an enhanced antioxidant capacity as compared to vitamin $\mathrm{E}$ acetate, because the former induced a significant decrease in oxidative stress, as determined by TBARS formation (Fig. 6). However, vitamin $\mathrm{E}$ acetate in high concentrations $(80 \mu \mathrm{M})$ was shown to be effective as an antioxidant (Fig. 6). The efficiency of vitamin E, as a chain-breaking antioxidant, and its reactivity against peroxyl radicals are due to its orientation, within the membranes, with the chroman head group toward the surface and with the hydrophobic chain buried in the hydrocarbon region (reviewed in Van Acker et al., 1993). In agreement with our results, in a neuronal system, $\alpha$-toco- pherol protected the cells against radical injury initiated by cumene hydroperoxide (Amano et al., 1994), or against ascorbate- $\mathrm{Fe}^{2+}$-mediated lipid peroxidation (Agostinho et al., 1997). Moreover, $\alpha$-tocopherol exists at a greater concentration in astrocytes than in neurons, which may be responsible for increased astrocyte resistance to oxidative stress (Makar et al., 1994). Vitamin E succinate was also shown to protect against the toxic effects of hyperoxia (Fariss, 1990) or from lipid peroxidation and cell death (Ray and Fariss, 1994).

The toxicity of high concentrations of vitamin E succinate, as compared to vitamin E acetate (Fig. 3), was intimately dependent to the amount of vitamin $E$ ( $\alpha$-tocopherol) incorporated in the cells, because the endogenous levels of vitamin $\mathrm{E}$ deriving from vitamin $\mathrm{E}$ succinate were larger than those that derived from vitamin $\mathrm{E}$ acetate (Table 1). Furthermore, we observed that the cellular content in $\alpha$-tocopherol from control retinal cells, not incubated with the vitamin E esters, is very low (Table 1), which may be due to a small amount of vitamin E present in the culture media, as reported by Kelley et al. (1995). Data from Table 1 suggested that, in the retinal cells in culture, the succinate ester was preferentially hydrolyzed into $\alpha$-tocopherol as compared to the acetate ester, which seems to be in accordance with a greater efficiency of vitamin E succinate in decreasing the extent of lipid peroxidation (Fig. 6). Nevertheless, vitamin E succinate $(20-80 \mu \mathrm{M})$ did not induce significant alterations in the membrane order of the retinal cells (Table 2), suggesting that vitamin $\mathrm{E}$ succinate did not cause the destabilization of the plasma membrane. Cheeseman et al. (1995) found that the initial rate of absorption into the plasma membrane of $\alpha$-tocopherol from the acetate ester was apparently higher than from the succinate ester, although the overall availability was the same for the two esters. Similarly, Liebler (1993) reported that a prolonged exposure to $\alpha$-tocopherol or to its esters (phosphate, succinate and acetate) increases the levels of $\alpha$-tocopherol at an equal rate.

Because vitamin E succinate was proposed to have a unique subcellular distribution, accumulating at the level of the mitochondria (Ray and 
Fariss, 1994), mitochondrial dysfunction, caused by high concentrations of vitamin $\mathrm{E}$ succinate, assumes great importance. Our results are highly suggestive that vitamin E succinate induces an alteration in mitochondrial activity, because a direct relationship between MTT reduction and ATP:ADP ratio was found. Although some recent work (Patel et al., 1996; Liu et al., 1997) indicates that the reduction of MTT does not take place exclusively in active mitochondria, it represents an early indicator of cell injury (Patel et al., 1996). The oxidation of vitamin $\mathrm{E}$ has been reported to occur in the mitochondria, prior to the depletion of other easily oxidized antioxidants (Vatassery et al., 1995). Furthermore, an increased availability of succinate, upon exposure of cells to vitamin $\mathrm{E}$ succinate, could be used by the mitochondria as a substrate of complex II to produce ATP. The subsequent release of $\alpha$-tocopherol and succinate by endogenous esterases could prevent the loss of mitochondrial membrane potential, mitochondrial ultrastructural changes and the loss of cell viability induced by exogenous mitochondrial toxic agents (Ray and Fariss, 1994). Our study is highly suggestive that this hypothesis could be valid only for low vitamin E succinate concentrations (up to $20 \mu \mathrm{M}$ ), but not for higher concentrations. The high concentration of vitamin E succinate is suggested to induce a loss of mitochondrial activity, since a decrease in MTT reduction and in ATP levels was observed.

Because, during cerebral ischemia, and especially upon reperfusion, the production of reactive oxygen species and lipid peroxidation occurs to a large extent, antioxidant protection afforded by vitamin E supplementation could constitute a basis for the prevention of oxidation cell injury. Taking into account that the unesterified form of vitamin $\mathrm{E}$ adheres to the plasma membrane without becoming incorporated, and that the more water-dispersible succinate ester is thought to be taken up by the cells, hydrolyzed by endogenous esterases and distributed to the cellular membranes (Liebler, 1993), this form of vitamin E could provide an effective and stable cytoprotector. Because we found that vitamin E succinate is toxic after supplementation in cultured retinal cells at high concentrations, further attention should be given to the dosage of vitamin E esters used for both experimental and therapeutic purposes.

\section{Acknowledgements}

This work was supported by JNICT and the Human and Capital Mobility Program (ERB 4050 PL 932039). We thank to Professor Carlos Duarte (Center for Neurosciences of Coimbra, Department of Zoology, University of Coimbra) for making CNQX and MK-801 available.

\section{References}

Agostinho, P., Duarte, C.B., Carvalho, A.P., Oliveira, C.R., 1994. Effect of oxidative stress on the release of $\left[{ }^{3} \mathrm{H}\right] \mathrm{GABA}$ in cultured chick retinal cells. Brain Res. 655, 213-221.

Agostinho, P., Duarte, C.B., Oliveira, C.R., 1996. Activity of ionotropic glutamate receptors in retinal cells: Effect of ascorbate $-\mathrm{Fe}^{2+}$-induced oxidative stress. J. Neurochem. 67, 1153-1163.

Agostinho, P., Duarte, C.B., Oliveira, C.R., 1997. Impairment of excitatory amino acid transporter activity by oxidative stress conditions in retinal cells: effect of antioxidants. FASEB J. 11, 154-163.

Amano, S., Ohashi, M., Kirihara, M., Yang, X.H., Hazama, F., 1994. $\alpha$-Tocopherol protects against radical-induced injury in cultured neurons. Neurosci. Lett. 170, 55-58.

Bergmeyer, H.U., Brent, E., 1974. UV-assay with pyruvate and NADH. In: Bergmeyer H.U., (Ed.), Methods of Enzymatic Analysis. Academic Press, New York, pp. 574-579.

Bjørneboe, A., Bjørneboe, G.-E., Drevon, C.A., 1990. Absorption, transport and distribution of vitamin E. J. Nutr. 120, 233-242.

Burton, G.W., Webb, A., Ingold, K.V., 1985. A mild, rapid and efficient method of lipid extraction for use in determining vitamin E/lipid ratios. Lipids 20, 29-39.

Cheeseman, K.H., Holley, A.E., Kelly, F.J., Wasil, M., Hughes, L., Burton, G., 1995. Biokinetics in humans of RRR- $\alpha$-tocopherol: the free phenol, acetate ester, and succinate ester forms of vitamin E. Free Radic. Biol. Med. 19, 591-598.

Fariss, M.W., 1990. Oxygen toxicity: unique cytoprotective properties of vitamin E succinate in hepatocytes. Free Radic. Biol. Med. 9, 333-343.

Huba, R., Hofmann, H.D., 1990. Identification of GABAergic amacrine cell-like neurons developing in retina monolayer cultures. Neurosci. Lett. 117, 37-42.

Keller, J.N., Pang, Z., Geddes, J.W., Begley, J.G., Genmeyer, A., Waeg, G., Mattson, H.P., 1997. Impairment of glucose and glutamate transport and induction of mitochondrial 
stress and dysfunction in synaptosomes by amyloid $\beta$-peptide: role of the lipid peroxidation product 4-hydroxynonenal. J. Neurochem. 69, 273-284.

Kelley, E.E., Buettner, G.R., Burns, C.P., 1995. Relative $\alpha$-tocopherol deficiency in cultured cells: free radical-mediated lipid peroxidation, lipid oxidizability, and cellular polyunsaturated fatty acid content. Arch. Biochem. Biophys. 319, $102-109$.

Leenheer, A.P.D., Bevere, V.O.R.C.D., Claeys, A.E., 1979. Measurement of $\alpha, \beta, \gamma$-tocopherol in serum by liquid chromatography. Clin. Chem. 25, 425-428.

Liebler, D.C., 1993. The role of metabolism in the antioxidant function of vitamin E. Crit. Rev. Toxicol. 23, 147-169.

Liu, Y., Peterson, D.A., Kimura, H., Schubert, D., 1997. Mechanism of cellular 3-(4,5-dimethylthiazol-2-yl)-2,5diphenyltetrazolium bromide (MTT) reduction. J. Neurochem. 69, 581-593.

Mabile, L., Fitoussi, G., Periquet, B., Schmitt, A., Salvayre, R., Nègre-Salvayre, A., 1995. $\alpha$-Tocopherol and trolox block the early intracellular events (TBARS and calcium rises) elicited by oxidized low density lipoproteins in cultured endothelial cells. Free Radic. Biol. Med. 19, 177187.

Makar, T.K., Nedergaard, M., Preuss, A., Gelbard, A.S., Perumal, A.S., Cooper, A.J.L., 1994. Vitamin E, ascorbate, glutathione, glutathione disulfide, and enzymes of glutathione metabolism in cultures of chick astrocytes and neurons: evidence that astrocytes play an important role in antioxidative processes in the brain. J. Neurochem. 62, $45-53$.

Martin, A., Zulueta, J., Hassoun, P., Blumberg, J.B., Meydani, M., 1996. Effect of vitamin E on hydrogen peroxide production by human vascular endothelial cells after hypoxia/reoxygenation. Free Radic. Biol. Med. 20, 99-105.

Mosmann, T., 1983. Rapid colorimetric assay for cellular growth and survival: application to proliferation and cytotoxicity assays. J. Immunol. Methods 65, 55-63.

Niki, E., Oikama, M., Takahashi, M., 1996. Oxidative cell damage induced by radicals and inhibited by antioxidants. In: Packer, L., Hiramatsu, M., Yoshikawa, T., (Eds.), Free Radicals in Brain Physiology and Disorders. Academic Press, San Diego, CA, pp. 35-43.

Patel, A.J., Gunasekera, S., Jen, A., Rohan de Silva, H.A., 1996. $\beta$-amyloid-mediated inhibition of redox activity (MTT reduction) is not an indicator of astroglial degeneration. NeuroReport 7, 2026-2030.

Ray, S.D., Fariss, M.W., 1994. Role of cellular energy status in tocopheryl hemisuccinate cytoprotection against ethyl methanesulfonate-induced toxicity. Arch. Biochem. Biophys. 311, 180-190.

Rego, A.C., Oliveira, C.R., 1995. Dual effect of lipid peroxidation on the membrane order of retinal cells in culture. Arch. Biochem. Biophys. 321, 127-136.

Rego, A.C., Duarte, E.P., Oliveira, C.R., 1996. Oxidative stress in acidic conditions increases the production of inositol phosphates in chick retinal cells in culture. Free Radic. Biol. Med. 20, 175-187.

Sedmak, J.J., Grossero, S.E., 1977. A rapid sensitive and versatile assay for protein using Coomassie Brilliant Blue G250. Anal. Biochem. 79, 544-552.

Shinitzky, M., Barenholz, Y., 1978. Fluidity parameters of lipid regions determined by fluorescence polarization. Biochim. Biophys. Acta 555, 367-394.

Smith, D., O'Leary, V.J., Darley-Usmar, V.M., 1993. The role of $\alpha$-tocopherol as a peroxyl radical scavenger in human low density lipoprotein. Biochem. Pharmacol. 45, 21952201.

Stocchi, V., Cucchiarini, L., Chiarantini, L., Palma, P., Crescentini, G., 1985. Simultaneous extraction and reversephase high-performance liquid chromatographic determination of adenine and pyridine nucleotides in human red blood cells. Anal. Biochem. 146, 118-124.

Van Acker, S.A.B.E., Koymans, L.M.H., Bast, A., 1993. Molecular pharmacology of vitamin E: structural aspects of antioxidant activity. Free Radic. Biol. Med. 15, 311328.

Van Blitterswijk, W.J., Van Hoeven, R.P., Van der Meer, B.W., 1981. Lipid structural order parameters (reciprocal of fluidity) in biomembranes derived from steady-state fluorescence polarization measurements. Biochim. Biophys. Acta 644, 323-332.

Vatassery, G.T., Maynard, U.R., Hagen, D.F., 1978. Highperformance liquid chromatography of various tocopherols. J. Chromatogr. 161, 299-302.

Vatassery, G.T., Smith, W.E., Quach, H.T., Lai, J.C.K., 1995. In vitro oxidation of vitamin $\mathrm{E}$, vitamin $\mathrm{C}$, thiols and cholesterol in rat brain mitochondria incubated with free radicals. Neurochem. Int. 26, 527-535.

Wills, E.D., 1969. Lipid peroxide formation in microsomes. General considerations. Biochem. J. 113, 315-324.

Yasui, Y., Mawatari, K., Higuchi, Y., Tanii, H., Kato, S., 1996. Oxygen radicals in glutamate toxicity of C6 glioma cells via transporter system. In: Packer, L., Hiramatsu, M., Yoshikawa, T. (Eds.), Free Radicals in Brain Physiology and Disorders. Academic Press, San Diego, CA, pp. 3543. 